\title{
Onset of Spermatogenesis in Corriedale Ram Lambs under Extensive Rearing Conditions in Uruguay
}

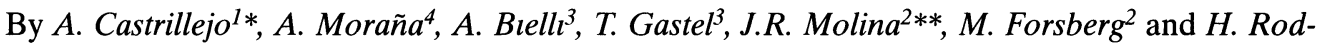 \\ riguez-Martinez ${ }^{1}$
}

Departments of ${ }^{1}$ Obstetrics and Gynaecology and ${ }^{2}$ Clınıcal Chemistry, Faculty of Veterinary Medicıne, Uppsala, Sweden, and Departments of ${ }^{3} \mathrm{H}$ istology \& Embryology, and ${ }^{4}$ Pathology, Faculty of Veterinary Medicıne, Uruguay.

\begin{abstract}
Castrillejo, A., A. Moraña, A. Bielli, T. Gastel, J. R. Molina, M. Forsberg and H. Rodriguez-Martinez: Onset of spermatogenesis in Corriedale ram lambs under extensive rearing conditions in Uruguay. Acta vet. scand. 1995, 36, 161-173. - The present study was undertaken to estımate the tıme for the attainment of spermatogenesis in springborn Corriedale ram lambs under conditions of extensive grazing systems in Uruguay. Clinical (live weight, scrotal circumference, penıle/preputıal separation), morphological(light and electron microscopy) and endocrinological (testosterone levels) parameters were examıned. Two experiments in 2 consecutıve years were carried out. In Exp. I, 40 ram lambs were clınically examıned, weighed, and blood-sampled at 2 week-intervals between 78 and 216 days of age. Sixteeen were castrated in 3 selected periods: 132162 (n. 2), 145-175 (n. 6) and 186-216 days (n. 8). In Exp. II, 40 ram lambs appertaınıng to the next generation of the same flock were examıned as above at 180-210 days of age, and castrated for morphological studies. The time for attainment of complete spermatogenesis correlated significantly with most corporal parameters (1.e scrotal circumference $(r=0.52)$, testıcular weight $(r=0.61)$, epıdidymal weight $(r=0.60)$, penıle/preputial separation $(r=0.75)$. The age of castrated ram lambs correlated with the degree of spermatogenesis $(r=0.83)$, although no significant correlations were found with live weight or with levels of circulatıng testosterone The histology showed major variations in the degree of development of the semıniferous epithelium. Cells undergoing degeneration were a common finding through the initial stages of spermatogenesis, coinc1dent to the presence of sperm abnormalities and foreign cells in semen. By day 180 and onwards, both histology and seminal picture normalized. It is concluded that, under these rearing conditions, the onset of puberty (expressed as morphologically established spermatogenesis) in Corriedale ram lambs is attained at 180-216 days of age when they reach $23 \mathrm{~cm}$ of scrotal circumference and $191 \mathrm{~g}$ of testıs weight. The finding of a high correlation between these parameters ( $r: 0.93)$ confirms the usefulness of the measurement of scrotal circumference during clinical examınation of ram lambs in this breed.
\end{abstract}

puberty; ultrastructure; testosterone.

\footnotetext{
*Permanent adresses: Joaquín Suarez 3132, CP 11800, Montevıdeo, Uruguay; **)Facultad de Agronomía, Unıversıdad de Costa Rıca, San José, Costa Rıca.
} 


\section{Introduction}

Many factors influence the age of onset of puberty in both sexes of sheep. Some breeds reach sexual maturity at an earlier age than others, indicating that the neuroendocrine development and the sequence of gonadal events that it induces is genetically controlled. Environmental factors affect attainment of puberty, mainly in relation to the growth rate of the animals. The development of the germinal epithelium is retarded by poor nutrition, a well-known fact (Phillips \& Andrews 1936). Low energy intake retards sexual development and delays puberty in ram lambs (Skinner \& Rowson 1968). Additionally, restricted nutrition reduces $\mathrm{LH}$ and FSH secretion and provokes poor testicular growth in ram lambs (Martin \& White 1992).

Corriedale is a Merino-derived medium-wool breed, well adapted to sub-tropical, sub-humid regions. Seventy percent of the world's stock is found within the southern South American region (Argentina, south of Brazil and Uruguay), Uruguay having $35 \%$ (approx. 18 million) of the world's corriedale population (Azzarini \& Cardellino 1984). Despite its economic importance, basic knowledge about the reproductive performance in this breed is lacking, and no published information is available about the age when ram lambs attain puberty.

A recent clinical survey of reproductive soundness in a total of 2952 Uruguayan rams showed that $4.7 \%$ of the unsound males had small testes (Castrillejo 1990) which might not only be congenital, but also arose from delayed puberty as a consequence of poor nutrition and endoparasites during the prepubertal period. Although testicular hypoplasia was suspected in many well-grown stud ram lambs, proper basic knowledge of the time of attainment of puberty is a prerequisite for an accurate diagnosis of possible pathologies.
The present study was therefore undertaken to establish the time of onset of spermatogenesis in Corriedale rams under extensive rearing conditions in Uruguay. Clinical, morphological, and endocrinological parameters were examined in spring-born (1-30th of September) ram lambs grazing natural pastures. The trial was undertaken in 2 experiments in consecutive years. In the first year, a wide range of live weight and age was included and, once the peripubertal weight and age was determined, this period was once again explored in the next generation of the flock in order to rule out possible climatic and nutritional year effects.

\section{Materials and methods}

\section{Animals and experimental design}

The experiments were carried out between December 1992 and April 1993 (Experiment I) and March-April 1994 (Experiment II) at a farm in Molles, Durazno, Uruguay ( $32^{\circ} \mathrm{SL}$ ) under extensive rearing conditions typical for the country. A total of 80 spring-born (1st to 30th of September) Corriedale ram lambs (40 in each experiment), were kept on natural pastures with their dams and with the same management throughout. The natural pastures consisted primarily of summer grasses (graminae, i.e. Paspalum spp, Axonopus, Sporobolus, Bothriochloa) with good availability although of varying quality (low digestibility, high fiber contents).

During Experiment I, 40 ram lambs were selected at random at age 3 months, (weight range: $10-28 \mathrm{~kg}$, average $17 \mathrm{~kg}$ ) from a total population of 260 animals. The selected animals were identified with collar-tags and thereafter, following a night of fasting, individually weighed, blood-sampled and clinically examined. The procedure was repeated at 2-weeks intervals up to 7 times. Blood was 

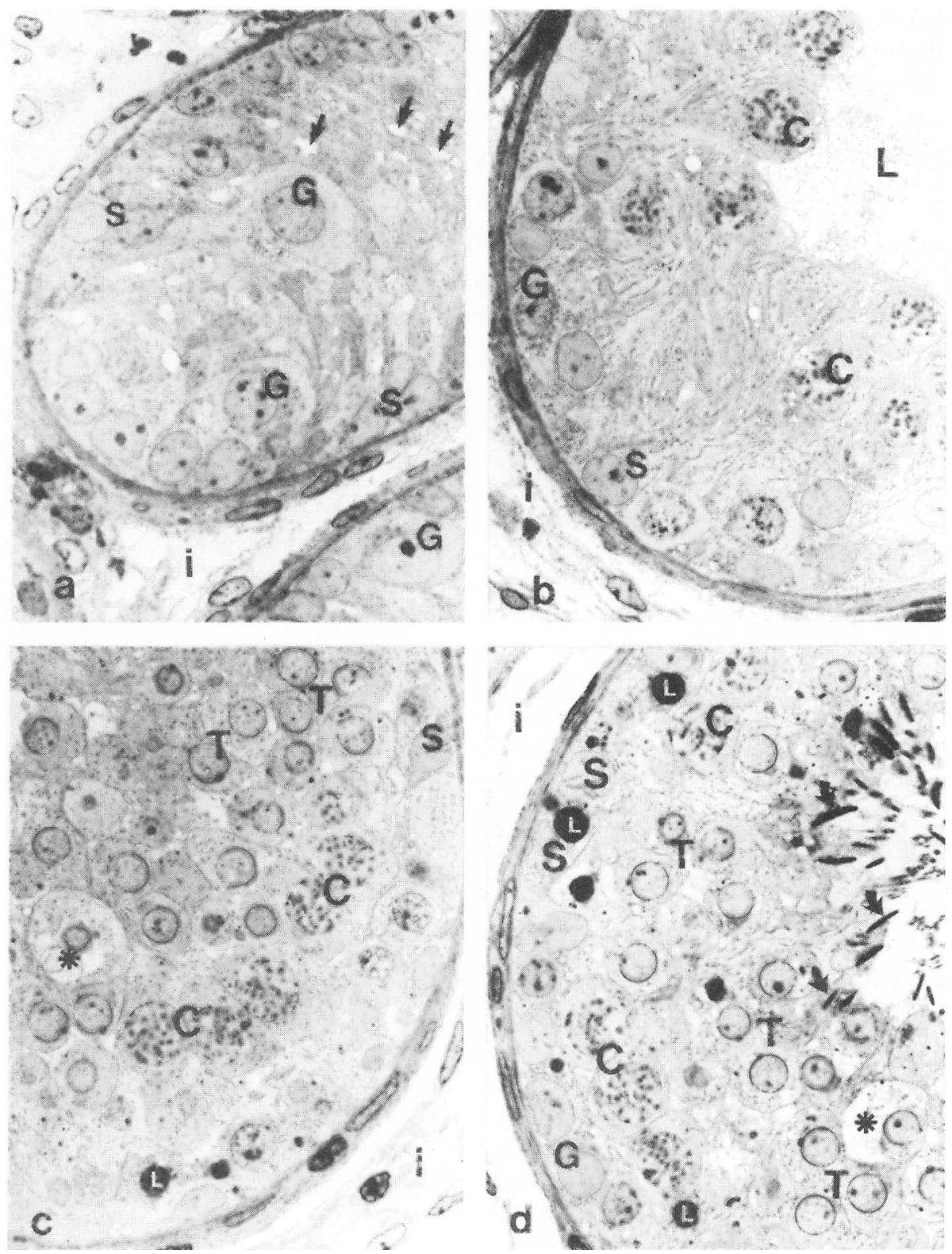

Figures 1a-d: Light microscopy of representatıve seminiferous cords/tubuli of peripubertal Corriedale ram lambs showing varıous degrees of spermatogenic differentiatıon. In (a) (score 0 ): a seminiferous cord is seen, holding barely Sertolı cells (S) and spermatogonia (G) while in (b) (score 1) and (c) (score 2) the tubuli show development of spermatocytes (C) and spermatids (T). In (d) (score 3) a complete seminiferous epithelium is seen where spermatogenesis had progressed to elongated spermatids (curved arrows). Degeneratıng spermatids were common $(*), \mathrm{L}$ : lipıd droplets, arrows: intercellular spaces; 1: interstitium (toluidine blue, 300x). 
sampled in glass tubes by jugular venipuncture, the blood serum harvested after spontaneous coagulation and kept at $-20^{\circ} \mathrm{C}$ until analysed for contents of testosterone. The ram lambs were thereafter clinically examined. The penis was manually exteriorized and the degree of separation of the preputial-penile mucosae was determined and registered as: 0 = no separation, $1=$ free urethral process while glans penis still attached, 2 = free glans penis and, 3 = free penis (adult aspect). Scrotal circumference (SC) was measured with a flexible tape at the widest scrotal diameter, the testes/epididymides were palpated, and the changes in size, consistency and resilience recorded throughout. Collection of semen by electroejaculation was thereafter attempted and, when successful, samples were both fixed in buffered formalin solution and smears prepared and air-dried.

Animals were randomly selected and castrated for morphological examination of the testes and epididymides between 132 and 162 $(n=2), 145$ and $175(n=6)$ or between 186 and 216 days of age $(n=8)$. The organs were weighed, measured and examined for morphological appearance and any abnormalities before sampling for histology. The cauda epididymides were excised and the contents collected in buffered formalin.

In Experiment II, 40 ram lambs belonging to the next generation of the same flock were selected from an initial ram population of 308 animals following individual weighing and clinical examination when reaching between 180 and 210 days of age. The selected rams had a live weight ranging from 24 to $33.5 \mathrm{~kg}$ (average $=28.5 \mathrm{~kg}$ ) and a scrotal circumference ranging from 16 to $29 \mathrm{~cm}$ (average 22.7 $\mathrm{cm})$. The animals were clinically examined, blood sampled and castrated for morphological examination of testes and epididymides as described above.

\section{Morphological examinations}

In both experiments, small ( $1 \mathrm{~mm}$ thick) tissue samples were excised from each testis at their proximal, medial (abepididymal) and distal areas and promptly immersed into a solution of glutaraldehyde in $0.067 \mathrm{M}$ cacodylate buffer ( $\mathrm{pH} \mathrm{7.2,} 500 \mathrm{mOsm})$ for fixation and further storage at $4^{\circ} \mathrm{C}$. Thereafter, the specimens were rinsed in cacodylate buffer at $4^{\circ} \mathrm{C}$, trimmed into smaller $\left(1 \mathrm{~mm}^{3}\right)$ selected pieces and post-treated in $2 \%$ osmium tetroxide. The tissue blocks were then dehydrated by exposure to graded concentrations of ethanol and propylene oxide and embedded into Agar 100 plastic resin (Agar-aids, Essex, England). Semi-thin sections $(1 \mu \mathrm{m})$ for light microscopy were cut on an LKB Ultratome ${ }^{\circledR}$ (Bromma, Sweden) and stained with buffered toluidine blue. The sections were examined on a light microscope (Olympus BH-2, Tokyo, Japan) to establish the degree of development of the seminiferous epithelium. The highest degree of germ cell differentiation present in each sample was scored as: $0=$ only spermatogonia, 1 = spermatocytes, 2 = round spermatids and, 3 = elongated spermatids and testicular spermatozoa (i.e. complete spermatogenesis).

Ultra-thin sections for transmission electron microscopy were cut from areas selected on the semi-thin sections. The ultrathin sections were picked up onto uncoated copper grids, counterstained with uranyl acetate and lead citrate and examined in a Philips EM $201^{\circledR}$ electron microscope at $60-80 \mathrm{kV}$ (Eindhoven, The Netherlands).

Sperm morphology was examined in both seminal and epididymal samples after staining with carbol-fuchsine (Williams 1920) and Papanicolaou (Ortho Diagnostics, New Jersey, USA) on a light microscope at $\times 1000$, and on wet preparations of the formalin-fixed samples using phase contrast optics at $\times 1000$. 

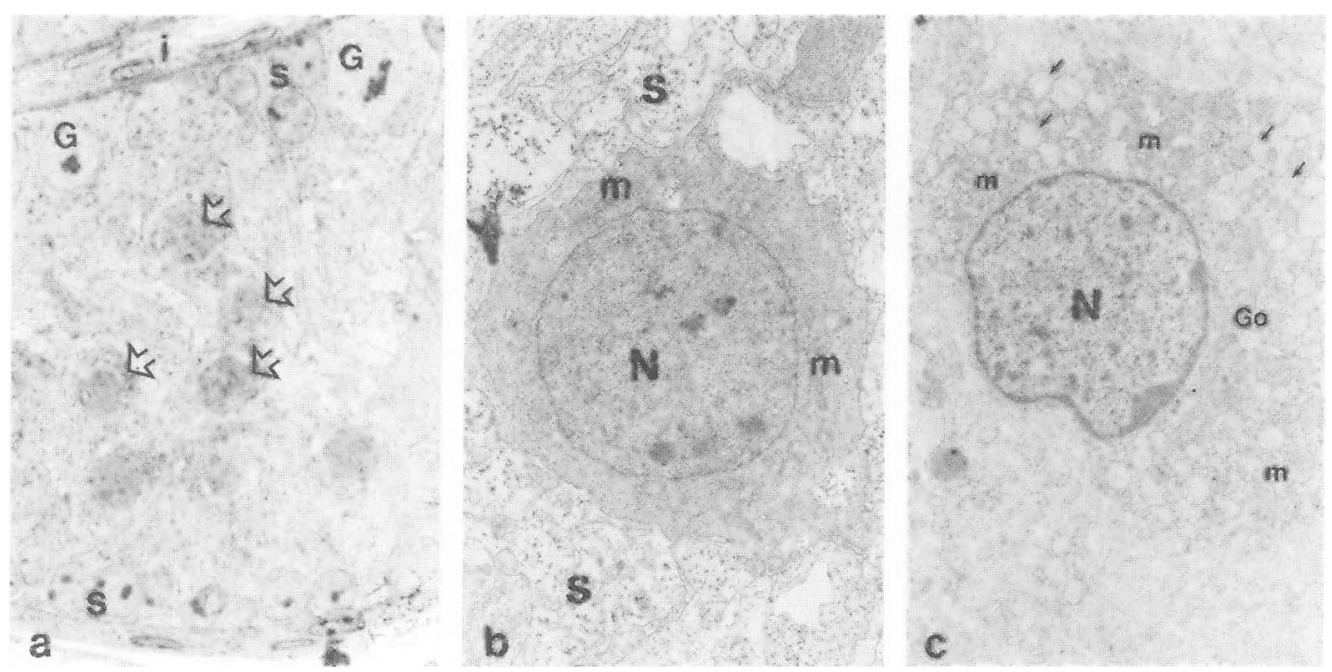

Figures $2 \mathrm{a}-\mathrm{c} \cdot$ Testicular tissue of a peripubertal Corriedale ram lamb (150 days old) showing in (a) (tolu1dine blue, $300 \times$ ) a seminiferous cord with Sertolı cells (S), spermatogonia $(G)$ and preleptotene-like cells (openarrows). Such a cell is depicted in (b) (2800x) among Sertolı cells (S) Figure (c) (2800x) shows an electron micrograph of a peripubertal Leydig cell. Note the abundant mitochondria $(\mathrm{m})$ and the dilated cisterna of the smooth endoplasmic reticulum (small arrows), Go. Golgı apparatus, N: nucleus).

\section{Hormone assay}

The peripheral blood serum samples were analyzed for testosterone content using a solid phase radioimmunoassay (Coat-A-Count, Total testosterone kit, DPC, New Haven, USA). The cross-reactions of the antiserum were $3.3 \%$ for dihydrotestosterone, $0.5 \%$ for androstenedione and less than $0.003 \%$ for all other substances tested. The limit of detection for the assay was $0.7 \mathrm{nmol} / \mathrm{l}$.

\section{Statistical analysis}

Statistical analyses (ANOVA, t-tests, correlations) of the results obtained were performed using the CSS:Statistica ${ }^{\circledR}$ program software (Statsoft, 1992, NY, USA).

\section{Results}

Significant gains in live weight were found throughout the first experiment (Exp. I) as shown in Table $1(\mathrm{p}<0.001)$. The ram lambs gained on average $134 \mathrm{~g}$ of body weight per day, a figure considered usual for the extensive rearing condition of the region. Discriminated by age-periods, a linear-like weight increase was seen up to 145-175 days, with a daily increment of $167 \mathrm{~g}$. Thereafter, the weight gain decreased to an average of 80.5 g/day.

Scrotal circumference values increased also significantly during the explored period (Table $1, \mathrm{p}<0.001$ ) with a major increase above 170 days of age (Table $1, \mathrm{p}<0.001$ ). Live weight and scrotal circumference values were significantly correlated $(\mathrm{r}=0.63)$. The preputial and penis mucosae were completely separated (adult aspect) in all animals with a scrotal circumference larger than $21 \mathrm{~cm}(>170$ days, Table 1). The mean maximum weight where animals did not have any separation of the penile/preputial mucosae (score 0) was 

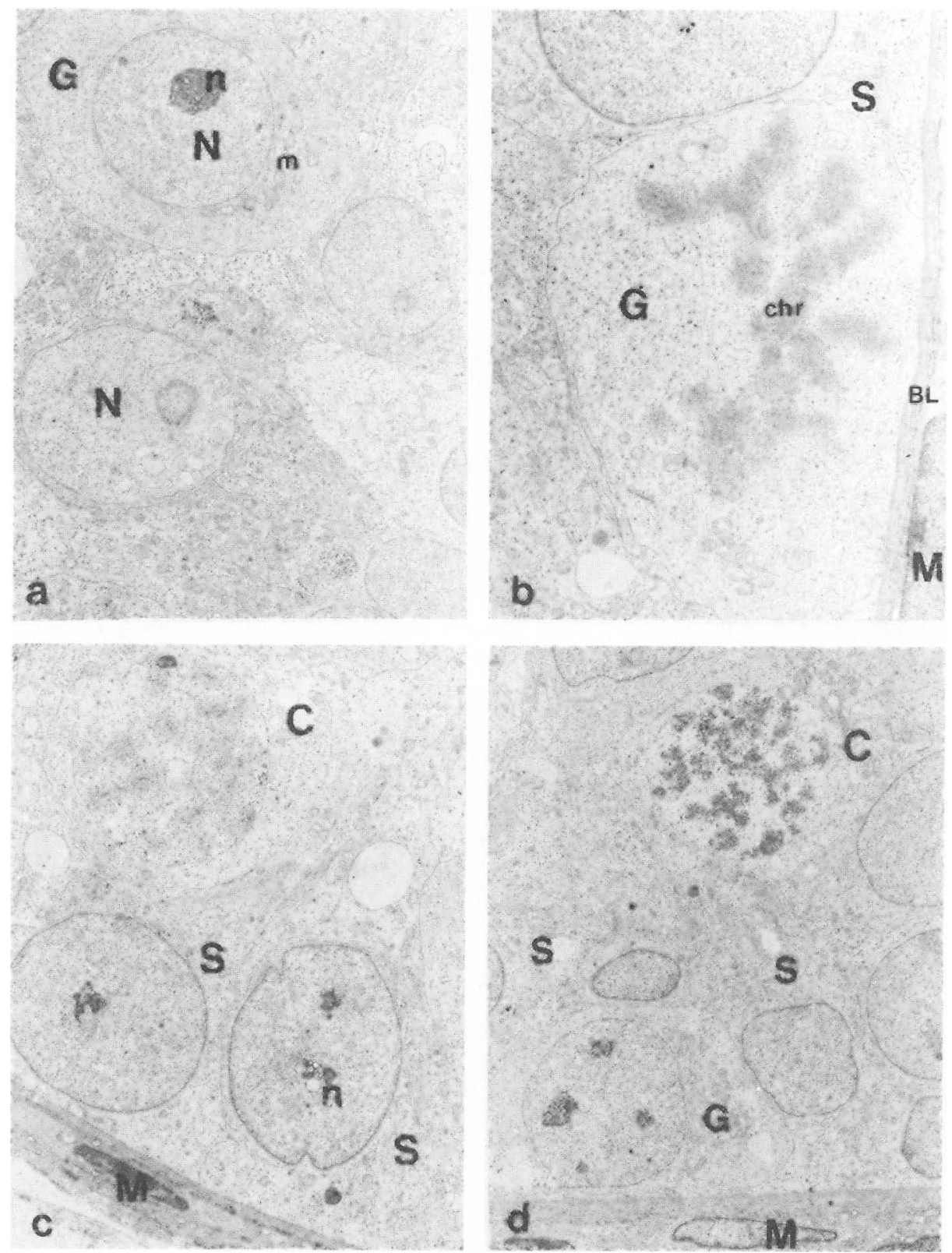

Figures $3 \mathrm{a}-\mathrm{d}$ : Electron mıcrographs of cord/tubulı semınıferı of perıpubertal Corrıedale ram lambs at ınitıation of spermatogenesıs, 145-175 days old (scores $0(a, b)$ and $1(c, d)$. In (a) $(1800 \times)$, spermatogonia (G) were the only visible germ cells, and mitosis was often seen (m: mitochondria) (b, 2800×, chr: chromosomes). Figures $c$ and $d(1800 \times)$ show the presence of spermatocytes $(C)$ in various prophase stages; S: Sertolı cells, M: myold cells, BL: basal lamina, $\mathrm{N}$ : nucleus, $\mathrm{n}$ : nucleolus. 

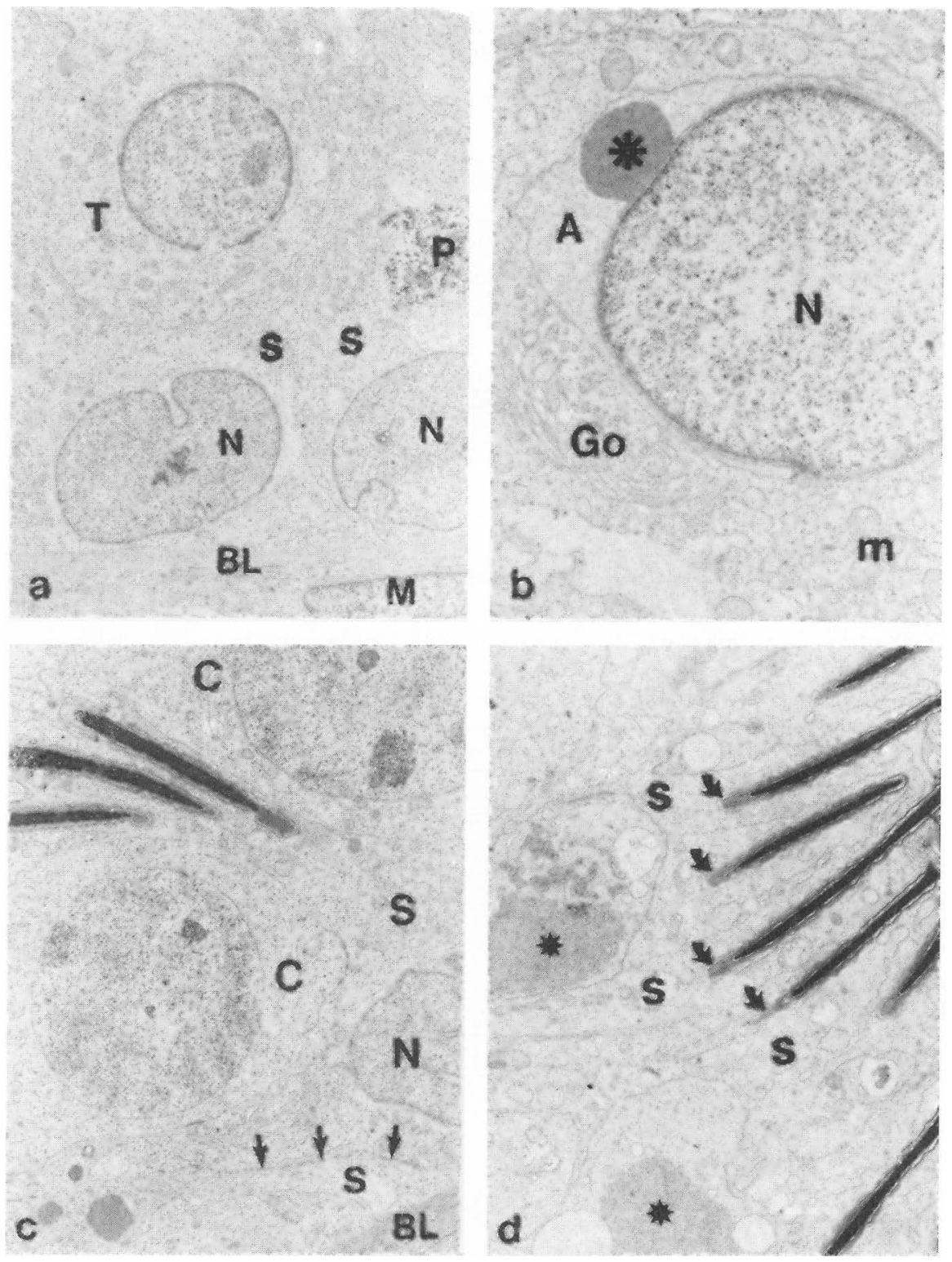

Figures $4 \mathrm{a}$-d: Electron micrographs of cord/tubulı semıniferı of peripubertal Corriedale ram lambs at medium to advanced spermatogenesis, more than 180 days old (scores $2(a, b)$ and $3(c, d)$. In (a) (2800x) and (b) $(8000 \times)$, round spermatıds $(T)$ were present durıng the various stages of spermiogenesis ((a) cap phase, step 5), (b) late cap phase, steps 5-6; Go: Golgı apparatus, A: acrosome vesicle and granule $(*)$ ) while spermatids in the final stages of elongation are seen in ((c) late acrosome phase, step 12; 4000x) and ((d) maturation phase, step 14-15; 4000×) (C: spermatocytes, small arrows: inter Sertoli cell-junctions, curved arrows: acrosome processes, *: cytoplasmic bodies, S: Sertoli cells, BL: basal lamina, N: nucleus, P: phagosomes, M: myoıd cell). 
Table 1: Live weight (LW, in kg), scrotal circumference ( $\mathrm{SC}$, in cm), testosterone levels ( $\mathrm{T}$, in nmol/l) and completed penile/preputial separation (PPS, in \%) of peripubertal Corriedale ram lambs grouped by age at sampling (days)(means $\pm \mathrm{SD})$.

\begin{tabular}{lccccc}
\hline Age (days) & $\begin{array}{l}\text { Number } \\
\text { of lambs }\end{array}$ & LW (kg)* & SC (cm)* & T (nmol/l)* & PPS (\%) \\
\hline $\begin{array}{l}\text { Experiment I. } \\
78-108\end{array}$ & 40 & $17.5 \pm 3.14$ & $10.8 \pm 1.68$ & s.o & 0 \\
$86-116$ & 40 & $18.8 \pm 2.90$ & $105 \pm 2.63$ & $3.4 \pm 16.11$ & 0 \\
$113-143$ & 40 & $227 \pm 3.40$ & $15.3 \pm 6.87$ & s.o. & 7.5 \\
$132-162$ & 40 & $266 \pm 3.78$ & $18.1 \pm 3.49$ & $1.4 \pm 1.58$ & 15 \\
$145-175$ & 38 & $28.7 \pm 3.02$ & $196 \pm 3.01$ & $6.4 \pm 7.36$ & 32 \\
$172-202$ & 32 & $30.3 \pm 2.49$ & $24.4 \pm 2.43$ & $1.9 \pm 2.00$ & 100 \\
$186-216$ & 32 & $32.0 \pm 265$ & $24.6 \pm 2.32$ & $0.9 \pm 0.39$ & 100 \\
& & & & & \\
Experiment II. & 40 & $28.5 \pm 2.81$ & $22.7 \pm 2.79$ & $2.2 \pm 1.67$ & 90 \\
$180-210$ & 40 & & &
\end{tabular}

s.o.: sampling omitted.

* Means withın columns differ significantly by age progression (ANOVA, $\mathrm{p}<005$ ).

Table 2: Degree of differentiation of the seminiferous epithelium in peripubertal Corriedale ram lambs based upon histology (DSg, $0=$ only spermatogonia, $1=$ spermatocytes, $2=$ round spermatids and, $3=$ elongated spermatıds) and grouped by age at sampling (Experıments I and II, $\mathrm{n}=56$ )

\begin{tabular}{lccccc}
\hline & \multicolumn{5}{c}{ Differentiation of the seminiferous epithelium } \\
\cline { 2 - 5 } Age (days) & $\mathrm{n}$ & 0 & 1 & 2 & 3 \\
\hline Experiment I. & 2 & 1 & 1 & - & - \\
$132-162$ & 6 & 2 & 3 & 1 & - \\
$145-175$ & 8 & - & - & 2 & 6 \\
$186-216$ & & & & 2 & 38 \\
Experiment II. & 40 & - & - & & \\
$180-210$ & &
\end{tabular}

$23.3 \pm 3.59 \mathrm{~kg}(\mathrm{n}=34)$ while the mean minimum weight where the separation was clinically completed (score 3 ) was $29.7 \pm 2.83$ ( $\mathrm{n}=$ 34).

No significant differences in live weight or scrotal cicumference were found between the same age intervals (180-216 days) in the 2 consecutive years (Exps. I and II, Table I), i.e. when animals had been considered as reaching puberty.

The peripheral levels of testosterone varied significantly through the study (Exp. I, Table $1, \mathrm{p}<0.05)$, although large variations were recorded in both Experiments (I and II). No significant correlations were detected among the various parameters and testosterone levels. The testes sampled throughout the experiments showed major variations in the degree of development of the seminiferous epithelium. Based upon the light microscopy of the semi-thin sections prepared, a scoring system was followed ranging from seminiferous cords 
Table 3. Live weight ( $\mathrm{LW}$, in $\mathrm{kg}$ ), scrotal circumference ( $\mathrm{SC}$, in $\mathrm{cm}$ ), total testicular weight ( $\mathrm{TW}$, in $\mathrm{g}$ ), total epıdıdymal weight (EW, in $\mathrm{g}$ ) and testosterone levels $(\mathrm{T}$, in $\mathrm{nmol} / \mathrm{l})$ of peripubertal Corriedale ram lambs grouped by the degree of differentiation of the seminiferous epithelıum (DSg, $0=$ only spermatogonia, $1=$ spermatocytes, 2 = round spermatıds and, $3=$ elongated spermatıds), based upon testıcular histology (Experıments I and II, means $\pm \mathrm{SD}, \mathrm{n}=56$ )

\begin{tabular}{lrrrrrr}
\hline DSg & $\mathrm{n}$ & LW $(\mathrm{Kg})^{\mathrm{ns}}$ & $\mathrm{SC}(\mathrm{cm})^{*}$ & $\mathrm{TW}(\mathrm{g})^{*}$ & EW $(\mathrm{g})^{*}$ & $\mathrm{~T}(\mathrm{nmol} /)^{\mathrm{ns}}$ \\
\hline 0 & 3 & $265 \pm 6.36$ & $17.2 \pm 389$ & $55.2 \pm 32.17$ & $13.3 \pm 3.35$ & $07 \pm 0.00$ \\
1 & 4 & $30.0 \pm 5.29$ & $19.7 \pm 2.78$ & $82.1 \pm 53.85$ & $19.6 \pm 3.33$ & $4.5 \pm 2.43$ \\
2 & 5 & $28.0 \pm 4.88$ & $197 \pm 3.93$ & $113.8 \pm 56.00$ & $19.7 \pm 2.79$ & $31 \pm 4.83$ \\
3 & 44 & $29.0 \pm 2.56$ & $233 \pm 2.46$ & $191.4 \pm 53.98$ & $288 \pm 2.66$ & $2.1 \pm 161$ \\
\hline
\end{tabular}

* Means within column differ significantly (ANOVA, $p<0.05$ )

Table 4: Percentages of sperm abnormalities in pubertal Corriedale ram lambs aged 180-216 days (Means $\pm \mathrm{SD}$ ).

\begin{tabular}{lcccccc}
\hline Age (days) & Abnorm heads & Abnorm tals & Prox drop & Dist drop & Loose heads & Abn midpleces \\
\hline $\begin{array}{l}\text { Experıment I } \\
186-216(10)\end{array}$ & $17.0 \pm 24.65$ & $11.8 \pm 15.64$ & $8.9 \pm 13.24$ & $0.3 \pm 0.94$ & $7.2 \pm 5.22$ & $1.6 \pm 275$ \\
$\begin{array}{l}\text { Expertment II } \\
180-210(40)\end{array}$ & $4.1 \pm 839$ & $4.2 \pm 590$ & $8.5 \pm 15.28$ & $1.6 \pm 5.68$ & $6.3 \pm 7.31$ & $0.1 \pm 0.28$ \\
\hline
\end{tabular}

with spermatogonia as single germ cells among Sertoli cells (Fig. 1a, score 0) to a fully developed seminiferous epithelium (score 3, Fig. 1d). The other scores (1 and 2) were merely intermediate forms (see Figs. $1 \mathrm{~b}$ and c). Cells undergoing degeneration were a common finding, particularly among the animals whose testicles began spermatogenesis (i.e. between scores 0 and 2, Figs. 2a-b). Additionally, the peripubertal Leydig cells were pleomorphic with abundant mitochondria and dilated cisterna of the smooth endoplasmic reticulum (Fig. 2c), particularly in testicular samples belonging to scores 1 and 2. Some Sertoli cells showed signs of degeneration in a few tubules, but without any obvious relation to age of sampling or stage of spermatogenesis.

The electron microscopy of the seminiferous cord/tubules of peripubertal Corriedale ram lambs (Figs. 3a-d, 4a-d) confirmed the previous cellular findings indicating that spermatogenesis was following a certain pattern along with the age intervals studied. The majority of the animals attained complete spermatogenesis by 180-216 days of age (Table 2), while none of the animals belonging to Experiment I had reached final spermiogenesis (i.e. had elongated spermatids in the seminiferous epithelium) by days 145-175 (Table 2). The correlation coefficient between date of sampling and degree of spermatogenesis (following the present scoring system) was $r=0.83$ (n: 56). Attainment of complete spermatogenesis correlated significantly with most physical parameters (Table 3), such as scrotal circumference $(r=0.52)$, testicular $(r=0.61)$ and epidydimal weight $(r=0.60)$ and separation of penile/preputial mucosae $(r=0.75)$. Further, scrotal circumference and testicular weight 
were very strongly correlated $(r=0.93)$. Spermatogenesis was not, however, significantly correlated with live weight $(r=0.08)$ or with the levels of circulating testosterone $(r=$ -0.13 ) for the studied population (Table 3 ).

Large variations in sperm abnormalities were found both at the cauda epididymides and semen samples from the rams in both experiments (age interval: 180-216 days). A tendency (n.s) towards a lower amount of abnormal sperm heads was recorded in Experiment II (Table 4). A conspicuous degree of other cells than sperm (particularly epithelial, boat cells and germ cells) was noticed among the rams with lighter testicles (data not shown).

\section{Discussion}

The present study showed that the time of attainment of complete spermatogenesis in Corriedale ram lambs raised on natural pastures correlated significantly with scrotal circumference, testicular, and epididymal weight as well as with the degree of separation of penile/preputial mucosae. The degree of attained spermatogenesis examined at light and electron microscopical levels correlated with age, but not with live weight or with levels of circulating testosterone. Using histology as a major grouping parameter, the present results indicate that, under these rearing conditions, the puberty in Corriedale lamb rams occurs between 180-216 days of age.

When considering postnatal development in ram lambs, corporal growth measured as increment in body weight has been recognized as a better indicator of the attainment of puberty than chronological age (Dunn 1955, Watson 1956, Pretorius \& Marincowitz 1968, Dýrmundsson \& Lees 1972). Spermatogenesis appeared to be in closer relationship with physiological age (i.e. live weight) than with chronological age in most of available studies that used testicular histology as a parameter to monitor puberty (Dýrmundsson 1973). A considerable variation has, however, been seen both within and between breeds.

On the contrary, the present study was carried out under extensive grazing conditions and showed a significant high correlation between attainment of complete spermatogenesis and chronological age $(r=0.83)$ without any correlation with live weight $(\mathrm{r}=0.08)$. However, Corriedale stud ram lambs grazing on improved pastures yielded semen at 150 days of age i.e. they attained puberty much earlier than the ram lambs included in the present experiments (Castrillejo, unpublished data). These differences imply that grazing on these natural pastures in Uruguay delays the onset of puberty impairing the expression of the genetic potential of the breed. Similarly, slow growth rates have been registered in Corriedale wethers with growing curves extended up to 3 years of age under the same conditions in Uruguay (Rodriguez 1990). The live weight of adult Corriedale rams grazing on the same pasture types as in the present study had been recorded as 49.4 and $54.2 \mathrm{~kg}$ at 18 and 27 months of age, respectively (Perez et al. 1992). Onset of spermatogenesis was therefore reached with $52-55 \%$ of the adult weight. Rams fed at higher nutrition planes attain puberty at an earlier age and at higher live weight than those on low nutritional planes (Skinner \& Rowson 1968, Pretorius \& Marincowitz 1968). The consequences of a poor general nutritional status upon the onset of puberty had pointed towards a delayed process (Alkass 1982, Lindsay et al. 1993). The present results fit well with these observations.

The ram lambs included in the present study gained on average $134 \mathrm{~g}$ of body weight per day, a figure considered usual for the exten- 
sive rearing condition of the region. However, an almost linear weight gain was seen up to 145-175 days, with a daily increment of $167 \mathrm{~g}$. Thereafter, the weight gain decreased significantly to an average of $80.5 \mathrm{~g} /$ day during the last 41 days of the experiment. During this last period, onset of spermatogenesis was registered in the animals selected for castration. Additionally, the age-period where testosterone levels increased (although with large individual variations) coincides with the change from a linear to an exponential type growth rate. However, this might not represent the only explanation for this slower growth rate, since, at the same time, the dominant grass species present in the fields usually increase their fiber contents, and therefore the digestibility decreases significantly.

In the present study, the increment in scrotal circumference showed a significant correlation with testicular weight $(r=0.93)$ despite the low growth rate of the animals. It further increased markedly from 170 days and onwards prior to the onset of spermatogenesis (as shown by the histological examinations). These findings confirmed previous studies (Dýrmundsson 1973). It is interesting, however, that the testicular weight at onset of spermatogenesis is lower than that given for the Merino breed (Watson 1956) despite the fact that Merinos have a lower adult weight than Corriedale rams.

The separation of the penile/preputial mucosae occurs more rapidly in heavier ram lambs, depending on growth rate (Skinner \& Rowson 1968). In the present study, the separation of the penile/preputial mucosae was not completed in all animals until they reached the 174 to 202 days age interval, with a live weight equal to that of animals with a mature seminiferous epithelium (180-216 days of age). This disagrees with previous observations by Watson (1956). The observed surge in testos- terone levels appeared in relation to the separation process as well as to the onset of the spermatogenesis.

The morphological examinations showed major variations in the degree of development of the seminiferous epithelium in relation to the age at sampling. Germ cells undergoing degeneration were a common finding through the initial stages of spermatogenesis leading to the presence of sperm abnormalities and foreign cells in semen and the epididymal tail contents. A larger number of abnormalities and/or foreign cells were present in those ram lambs with lighter testes and therefore immature from a histological point of view. The distribution and frequency of sperm abnormalities were comparable with those values cited by Skınner \& Rowson (1968) for Suffolk and cross-bred rams.

From the data obtained in the present study it is concluded that, under these rearing conditions, the onset of puberty (expressed as morphologically established spermatogenesis) in Uruguayan Corriedale lamb rams is delayed until 180-216 days of age when they reach 23 $\mathrm{cm}$ of scrotal circumference and $190 \mathrm{~g}$ of testicular weight. The finding of a high correlation between these parameters $(r=0.93)$ confirms the usefulness of the measurement of scrotal circumference during clinical examination of ram lambs in this breed. Further studies, including different levels of feeding, are necessary to determine the potentiality of this breed to attain puberty at an earlier age.

\section{Acknowledgement}

The authors wish to thank Mrs. M. Ekwall for excellent technical assistance with the processing for electron microscopy. Partial financial support. was received by the Swedish University of Agricultural Sciences, the Swedish Council for Forestry and Agricultural Research and the Swedish Agency for Research Cooperation with Developing Countries (SAREC). 


\section{References}

Alkass JE, Bryant JJ, Walton JS Some effects of level of feeding and body conditions upon sperm production and gonadotrophin concentrations in the ram. An. Prod. 1982, 34, 265-273.

Azzarını M, Cardellino $R \cdot$ Algunas consideraciones sobre programas de mejoramiento genético del Corriedale del Uruguay (Some considerations about genetic improvement programmes for the Corriedale breed in Uruguay). SUL, Boletín Técnico No. 12, 1984.

Castrillejo A. Clinic survey of reproductive soundness in rams. Veterınarıa (Uruguay) 1990, 26, 1219

Dunn $R B$ Puberty in Merıno rams. Aust vet. J. 1955, 31, 104-106.

Dýrmundsson OR. Puberty and early reproductıve performance in sheep II. Ram lambs. An. Breed. Abstr. 1973, 41, 419-430.

Dýrmundsson OR, Lees JL Puberal development of Clun Forest ram lambs in relation to time of birth J. agric. Scl., UK 1972, 79, 83-89

Lindsay DR, Martın GB, Willams IH Nutrition and Reproduction. In: King GJ (ed) Reproduction of Domesticated Anımals World Anım. Scı., Vol 9, Chapter 17. 459-485, Elsevier Science Publ, Amsterdam, 1993.

Martın GB, White CL: Effects of dietary zınc deficiency on gonadotrophin secretion and testicular growth in young male sheep J. Reprod Fert, 1992, 96, 497-507

Perez Clarıget R, Castrillejo A, Lopez A, Laborde D, Queirolo D, Franco J. Reproductive seasonality in rams. Proc. 5th National Vet. Congr., Montev1deo, Uruguay, Nov. 1992, I: 86-90.

Phillps RW, Andrews FN The development of the testes and scrotum of the ram, bull and boar. Agr. Exp. Stat. Massachusetts., 1936, Bulletın 331

Pretorius PS, Marincowitz G: Post-natal penis development, testes descent and puberty in Merino ram lambs on different planes of nutrition. South African J. Agric Scl., 1968, 11, 319-334

Rodriguez A. Importancia de la recria en los sistemas de produccion ovina (Importance of rebreeding in ovine production systems). III Sem. Tecn. Prod. Ovina, SUL, Paysandú, Uruguay, 1990, 129-145.

Skınner JD, Rowson LEA. Puberty in Suffolk and Cross-bred rams. J. Reprod Fert. 1968, 16, 479488.

Skinner, JD, Booth WD, Rowson LEA, Karg H: The post-natal development of the reproductive tract of the Suffolk ram, and changes in the gonadotrophic content of the pituitary. J. Reprod Fert. 1968, 16, 463-477

Watson RH, Sapsford ES, McCance I. The development of testis, epididymis and penis in the young Merıno ram. Aust J. agric. Res. 1956, 7, 574-590.

Wiggins EL, Terrill CE Variation in penis development in ram lambs J Anım. Sc1. 1953, 12, 524535.

Willaams $W W$ Technique of collectıng semen for laboratory examination with a review of several diseased bulls. Cornell Vet. 1920, 10, 87-94

\section{Sammanfattning}

Spermatogenes hos Corriedale bagglamm under extensıva betesforhållanden ı Uruguay

Syftet med undersoknıngen var att faststalla sperm1ebıldnıngens utvecklıng hos vårfodda Corriedale lamm uppfodda under extensiva betesforhållanden 1 Uruguay I det forsta årets experıment ingick 40 bagglamm som undersoktes mellan 78 och 216 dagars ålder. Var fjortonde dag vagdes djuren och testıkelomkrets och penis/forhudsseparation registrerades. Dessutom togs blodprover dar testosteron analyserades. Sexton av djuren kastrerades vid 3 tidpunkter dag 132-162 $(\mathrm{n}=2)$, dag 145-175 $(\mathrm{n}=6)$ och dag 186$216(n=8)$. Testıklar och bitestıklar vagdes och vavnaden undersoktes morfologiskt med ljus- och elektronmıkroskopı med avseende på spermatogenes. Efterfoljande år undersoktes 40 djur 1 samma flock på motsvarande satt med provtagningar och kastration av samtliga djur mellan 180 - 210 dagars ålder. Det var en god overensstammelse mellan fullt utvecklad spermatogenes och ovriga parametrar som undersoktes (testıkelomkrets, $r=0,52$, testıkelvikt, $r=0,61$; penıs/forhudsseparation, $r=0,75$ ). Det var också en god korrelation mellan ålder vid kastration och spermatogenes $(r=0,83)$. Daremot kunde man inte finna något samband mellan spermıebıldnıngens utvecklıng och levande vikt eller serumkoncentration av testosteron De histologiska undersokningarna visade stora variationer 1 utvecklıngen av sadesepitelet Degenererade celler var ett vanligt fynd 1 det initiala stadiet av spermatogenesen, vllket gav en hog andel onormala spermier och frammande celler 1 sadesvatskan. Från dag 180 och framåt normalıserades bilden Slutsatsen av undersoknıngen var att Corriedale lamm uppfodda under extensiva forhållanden kommer 1 pubertet (spermatogenesen bedomd morfologiskt) vid 180- 
216 dagars ålder nar testıkelomkretsen ar ca $23 \mathrm{~cm}$ och testıkel-vıkten ca 191 gram Den hoga korrelationen mellan dessa parametrar $(r=0,93)$ styrker att testıkelomkrets ar ett bra klınıskt mått for att bedoma pubertetens intradande hos bagglamm av Corriedaleras

(Recelved November 2, 1993, accepted December 12, 1994)

Reprints may be requested from. H. Rodriguez-Martınez, Dept of Obstetrics \& Gynaecology, Faculty of Veterınary Medicıne, Swedısh Unıversity of Agrıcultural Sciences, P.O. Box 7039, S-750 07 Uppsala, Sweden. 
